\title{
Factors Influencing Professional Selection Choices: Evidence from Pakistan
}

\author{
Alishba Pasha \\ Research scholar, Karachi university business school, university of Karachi, Pakistan \\ Dr. Danish Ahmed Siddiqui \\ Associate professor, Karachi university business school, university of Karachi, Pakistan
}

\begin{abstract}
:
This empirical study was conducted to identify the different factors that influence Pakistani student's career choices. Five leading professions i.e. business and management sciences, medical, pharmacy, engineering and agriculture were selected to identify the factors. A survey was conducted using close ended Likert scale type questionnaire on the sample of 523 students from mentioned background. Multi-criteria decision analysis technique apply to rank the professions from best to worse one by using PROMETHEE. Further analysis was done by using Structured Equation Modelling and Confirmatory Factor Analysis technique. The results suggests that medical profession is superior among other professions. The result also indicate that personal interest, selfesteem and societal influence were major factors that significantly impact career selection of business and management. For medical profession, self-efficacy and self-esteem found to have a positive influence. For pharmacy profession, growth opportunities, psychological factor, self-efficacy and self-esteem have a significant influence. For engineering profession psychological factor, self-efficacy and societal influence show positive affect. For agriculture profession, self-esteem, psychological factor and growth opportunities show favorable results. The findings of the study will help students who want to peruse any of the above mentioned professions. This study open ups the door for career guidance and counselling in Pakistan and provide valuable information to policy makers and recruiters as to keep in mind the factors that affect students when they associated with these professions.
\end{abstract}

Keywords: profession selection, career choices, Pakistani students, PROMETHEE, self-esteem, PLS-SEM

DOI: $10.7176 / \mathrm{EJBM} / 11-36-16$

Publication date: December $31^{\text {st }} 2019$

\section{INTRODUCTION:}

Profession selection is an important decision for any student. When we talk about the career choices or profession selection the question that comes in our minds is what the students would like to be and why? The answer of this question usually depends on student interest, parental background, environmental and societal influences etc. it means we can say that selection of profession for students will vary culture to culture, person to person and society to society. Mostly students choose such type of professions that have high market value, growth opportunities, job security, financial benefits and highly respectable in society. Doctors, engineers, pharmacist, business managers are the people whom the students admired and wants to be like them. Moreover agriculture profession also taking attention of students due to market acceptability. All these professions have high demand among the students and higher education institutions provide opportunities to be specialized in these disciplines which ultimately help students in their career development.

Profession selection is the important element in today's modern life and highly competitive environment. Life revolves around different professions which gives identity and creativity, purpose and self fulfilment, it connects us with social networking (Choo, Norsiah, \& Tan, 2012). Student life is linked with different experiences and attitudes related to that profession or field they choose. Any student who decides to select a particular profession two conditions are necessary for him/her. First, other career and profession options are available and secondly personal interest and preference is matter most between different professions (Agarwala, 2008a). Different profession selection options given to the individual or students are influenced by external factor such as economy, labor market etc. and internal factors include family, behavior, attitudes and background (Agarwala, 2008a). Environmental, political, economic, socio culture aspects are also affect the profession selection decisions of young students.

\subsection{Problem Statement}

Selection of a career or profession that matches with your abilities, skills, interests and personality is a critical decision. Unfortunately in developing countries like Pakistan there is a lake of career consoling and guidance and students do not have sufficient knowledge about their selected profession. In Pakistan the literacy rate is low there are many factors that could affect the choice of students. Sometimes the parents imposed their choices on students to select professions they decided for them. So there is a need to identify different factors that impact on Pakistani students in career selection process. 
In Pakistan there is a shortage of research on profession selection context. This paper explores the factors that affect the Pakistani students in their profession selection decision. Questions like why students select their specific profession? What were the reasons behind their decision? Were their decisions under influenced or not? Is there any role of self-efficacy and self-esteem in their profession selection decisions? All of the above questions has been explored in this research.

\subsection{Gap Analysis}

Based on the extensive literature review it has been observed that many researches has been conducted on career choices like (Jones \& Larke Jr., 2003) who stated that father was a influencing factor in selection of agriculture profession in USA. Another author (Agarwala, 2008a) identify the impact of cultural values that affect career choices of MBA students in India. The author (Dick \& Rallis, 2006) stated that societal influence is the most important factor in the selection of engineering profession in Rhode island, but another author $(\mathrm{Ng}$, Burke, \& Fiksenbaum, 2008) confirmed that societal influence was not a significant factor in career selection process in USA. The author (Choo et al., 2012) also stated that in Malaysia societal influence is not a significant factor for career selection. The author (Bai, 1998) identify the impact of market oriented economy on career selection process in Chinese universities.

In short all the above researches has been conducted on a particular profession and most of the researchers examined the cultural and market oriented impact on career selection. Moreover all these researches have been conducted in a specific socio-cultural environment like in India, china, Malaysia, USA and the factors that is favorable in one country surely unfavorable in other country. In Pakistan the study conducted by (Nauman, 2014) explored the career influencing factors in Punjab regions which is obviously different in Karachi as Karachi is the biggest commercial city of Pakistan that have a population more than 20 crore according to the census of 2017, so the result of the study cannot generalized in Karachi. The sample size of the study is relatively small that limits the scope of the research. In addition, this study does not include any university from Karachi so there is a need to fulfill this cross-culture gap because cultural diversity is a important aspect in career choice decisions that cannot be ignored. Moreover in Pakistan there is a lack of education and illiteracy rate is high, also a lack of career guidance and counselors who gives proper advise to Pakistani students in their career selection process.

\subsection{Research objectives}

For the purpose of meaningful work life, profession selection is the important decision for every student. There may be a number of reasons behind the profession selection decision of any student so there is need to identify those factors that affect career decisions. For the sake of this study we take a large number of students that have different educational backgrounds and interrogate them to identify the factors that influence them with the help of well-structured questionnaire. Following are the objectives of study:

- To study the impact of factors that influence the selection of business and management sciences profession.

- To study the impact of factors that influence the selection of medical profession.

- To study the impact of factors that influence the selection of pharmacy profession.

- To study the impact of factors that influence the selection of engineering profession.

- To study the impact of factors that influence the selection of agriculture profession.

\subsection{Research questions}

What are the factors that affect the students to select management and administrative sciences field?

What are the factors that affect the students to select medical profession?

What are the factors that affect the students to select pharmacy profession?

What are the factors that affect the students to select engineering profession?

What are the factors that affect the students to select agriculture profession?

\subsection{Significance}

Pakistan is facing a problems like poverty, illiteracy, corruption, energy crisis but except all, there are some other issues like career decisions that not give any importance from our government educational officials. Pakistani youth does not know about what they wants to become, what are there wants, skills and abilities. This research examined the students of Pakistan especially in Karachi who are studying in different universities. This research helps the Pakistani youth in career selection of five different leading professions as this research identified the significant factors for the selection of profession. This research elaborates the details of Pakistani student's expectations and reasons to select any particular professions, so the organizations and industries can provide the person-environmental fit and career attainment to the students. Pakistani youth needs a career counselling and with the help of this research higher education commission Pakistan can appoint career counsellors in all private and government institutions that give directions to students. 


\section{Literature Review:}

Career explorations have two dimensions first is self-exploration and second is environmental exploration. In self-exploration person has its own interest, values, attitudes, curiosity to understand his/her personality in order to search for a career match (Flum, Behavior, \& 2000, 2000) and in environmental exploration people search other career options by gathering the information on job vacancies, attractive occupations and industries to take more careful decision of profession selection (Zikic \& Richardson, 2007). When we combine both self-exploration and environmental exploration we get information about individual personal interest, experiences, abilities that match some specific profession or occupation and thus we achieve person environmental fit and career attainment (Ballout, 2007). Many researchers have focused different factors that influence profession selection decisions largely based on student interest, growth opportunities, individual aptitudes and past studies also showed many factors that affect profession selection decisions like occupational charm, societal influence, job security, academic achievements, salary, status and prestige, work autonomy etc (Nauman, 2014). Three dimensional frame work has been proposed by (Carpenter \& foster, 1977) are widely used in profession or career selection studies, these factors are intrinsic which means (interest in the job and personally satisfying work) second is extrinsic which means (availability of jobs and high paid salary structures) and third factor is interpersonal which means (societal influence like parents, teachers, siblings, friends) (Carpenter \& foster, 1977) (Beynon, Toohey, Journal, \& 1998, 1998).

Similarly other authors (Jones \& Larke Jr., 2003) have identified that father occupation is a most important aspect in career selection decisions of students, according to the author students whose father were employed in agriculture related occupation so most probably there is a chance that a child will pursue an agriculture related career and those students whose father were not in agriculture related occupation so a child will pursue any other professions, moreover college experiences, career fairs, internships, experimental exposure, cooperative work programs may have a positive impact on students profession selection decisions and if the job opportunities is limited and students will not be able to find their ideal career so they prefer other occupations. Parents, teachers plays a critical role in students career selection decisions because they act as a role model for any student (Jones \& Larke Jr., 2003). The author (Dick \& Rallis, 2006) have also identified that parents and teachers are the most powerful personalities to encourage the students both male and female to choose science or engineering fields. According to the author money or income is a influencing factor for men and personal interest is a important factor for women to choose a specific profession (Dick \& Rallis, 2006)..

Another valuable studies showed that under the societal influence father is considered to be a greatest influence of MBA students in India to shape their career choices decisions (Agarwala, 2008b). According to this study for management sciences student abilities, skills, competencies, education and training is the most significant factor to influence their decisions (Agarwala, 2008b). Moreover this study also explored the cultural values that affect career selection decisions. According to this study MBA students in India have both individualistic and collectivistic culture values which means those students who have individualistic behavior will value his/her own interest, they consider as independent of organizations, they give themselves a higher value on self-reliance, they are looking for their own advantage, they concern their own individual financial security, social status and career progression (Agarwala, 2008b). individualistic behavior students believes that they are responsible for their career decision and their future (Agarwala, 2008b). According to the study individualistic behavior students in India gives more important to material benefits like money, financial rewards, salary, social status and prestige. This study proved that Indian management students who have highly influenced in individualistic culture will not give value to family members, relationships and social networks while taking profession selection decisions, on the other hand those students who have high collectivism give value and take support from others like family members, teachers, siblings etc in their career selection process so father is considered to be a most influential person that shape the children career decision process in management sciences in India (Agarwala, 2008b), this study also expose two types of career orientations protean and conventional. Indian management students have a mix of both orientations. Protean individuals are those who managed proactively, they are self- directed, value driven, and career selection decision will not influenced by people. On the other hand conventional orientation individuals are not self-directed, they measure the success in terms of objective factors like promotions, recognitions, money etc, so their profession selection decision influenced by success stories of others such as father, mother, etc (Agarwala, 2008b). This study also observed that for females students in India intrinsic factors are most important like skills and competencies for the selection of management career but for male students extrinsic factors are more important such as financial rewards (Agarwala, 2008b). On the contrary another author ( $\mathrm{Ng}$ et al., 2008)explored that the influence of people such as family and non-family members, relatives have limited effect on career decision which means that societal influence has no significant relationship with career selection process. According to this author the expectation of US MBA students are " knowledge and competence" from an MBA program and US students showed greater value and success in their MBA program ( $\mathrm{Ng}$ et al., 2008). Moreover US MBA students also showed high scoring on individualism and collectivism behavior just like protean career orientation, and non- 
people factor which include (education and training, career benefits, luck and chance) also influenced the profession selection of US MBA students ( $\mathrm{Ng}$ et al., 2008). Similarly another author also exposed that family influence does not affect the career choices of engineering students (Choo et al., 2012). The factors that affect the choice of engineering profession is job-fit which means the perception of individual personality that meets the job requirement and demands, job demands include (knowledge, abilities, skills) (Choo et al., 2012), a student that have a good educational background in engineering have a possibility to select engineering profession because they believe that they have skills to handle this technical profession in future (Choo et al., 2012). This study also confirms the another factor that is financial rewards in career selection decision likewise (Agarwala, 2008a). financial rewards and benefits are the positive relationship on the career choices among engineers (Choo et al., 2012). So human resource management have an important role in providing an appropriate job scope to engineering students to enhance their skills and capabilities and to motivate them. Conversely another author exposed that financial rewards and income is not a significant factor in the selection of pharmacy profession (Eiland et al., 2010), according to this study there is a perception of pharmacy faculty that students not choose this profession due to low salary in academia and high salary outside the academia that forces the students not to choose this profession but low patient contact was the most significant reason of students not to choose this field, this study confirms that $77 \%$ of the students said that low salary is not a reason to not to choose pharmacy profession (Eiland et al., 2010). According to the other studies growth or career opportunities is the important factor for students to choose pharmacy profession and those students who have desire to help others, confidence in their abilities and have more knowledge of this profession are the other factors to select pharmacy profession (Flora., 2010). Gender influence has also been observed by this author that females supposed to be more concern, sensitive, empathy and compassion in nature so they select or prefer pharmacy as a profession (Flora., 2010).

Another author empirically verified different factors that affect the career choices of accountants, attorneys, engineers and physicians (paolillo \& estes, 1992). According to the author employment opportunities is the biggest factor that affect the career choices of accountant students, on the other hand for attorneys the most important factor is social status and least important factor is teacher influence, similarly for engineers employment opportunities is also important likewise for accountants and social status is the least important factor for engineers and for physicians parental influence or peer influence are the important factor while earning potential and work experience are the less important factors (paolillo \& estes, 1992). The author (Wilkinson, 2006) observed the differences between men and women in choosing their first employment in civil engineering profession in UK. According to this study women considers the location of the organization more than men, women's want to live close and near to family and friends, so according to the author mobility is the factor that affect the civil engineering students of UK in the selection of their career paths (Wilkinson, 2006). The findings of the another author also stated that for females in US, chance, luck or circumstances is the important factor in the selection of management career ( $\mathrm{Ng}$ et al., 2008).

Author (Bai, 1998) said that under the influence of market orientation economy the choices of university graduates affected. He observed that university students are confused between personal interest and interest of others, individual freedom and social responsibility, market competition and fairness, he observed that personal elf interest is the factor that shape their career decisions rather than societal interest (Bai, 1998). Like other professions, medical profession is also taking attention from young graduates due to its significant impact on society and on the lives of people. According to the author (kassebaum \& szenas, 1993) explored various important factor that influence the specialty choices of medical students, these factors are intellectual opportunity which include (content of the specialty, opportunity for research, diagnostic problem), lifestyles, personality-fit to the specialty and interest in helping people, on the other hand like time and flexibility, clerkships, mentorship, faculty encouragement have moderate influence, moreover leadership and prestige are the most influencing factor for surgical specialties (kassebaum \& szenas, 1993). The another study also confirmed the factors that affect the career choices in internal medicine these factors are practice environment, educational experiences, patient care, intellectual challenge, role models, personal/professional satisfaction, lifestyles and prestige (K.E. et al., 2008).

\section{Theoretical framework}

The aim of this study is to identify the factors that affect the selection of various leading professions in Pakistan like business and management sciences, medical, pharmacy, engineering and agriculture. 


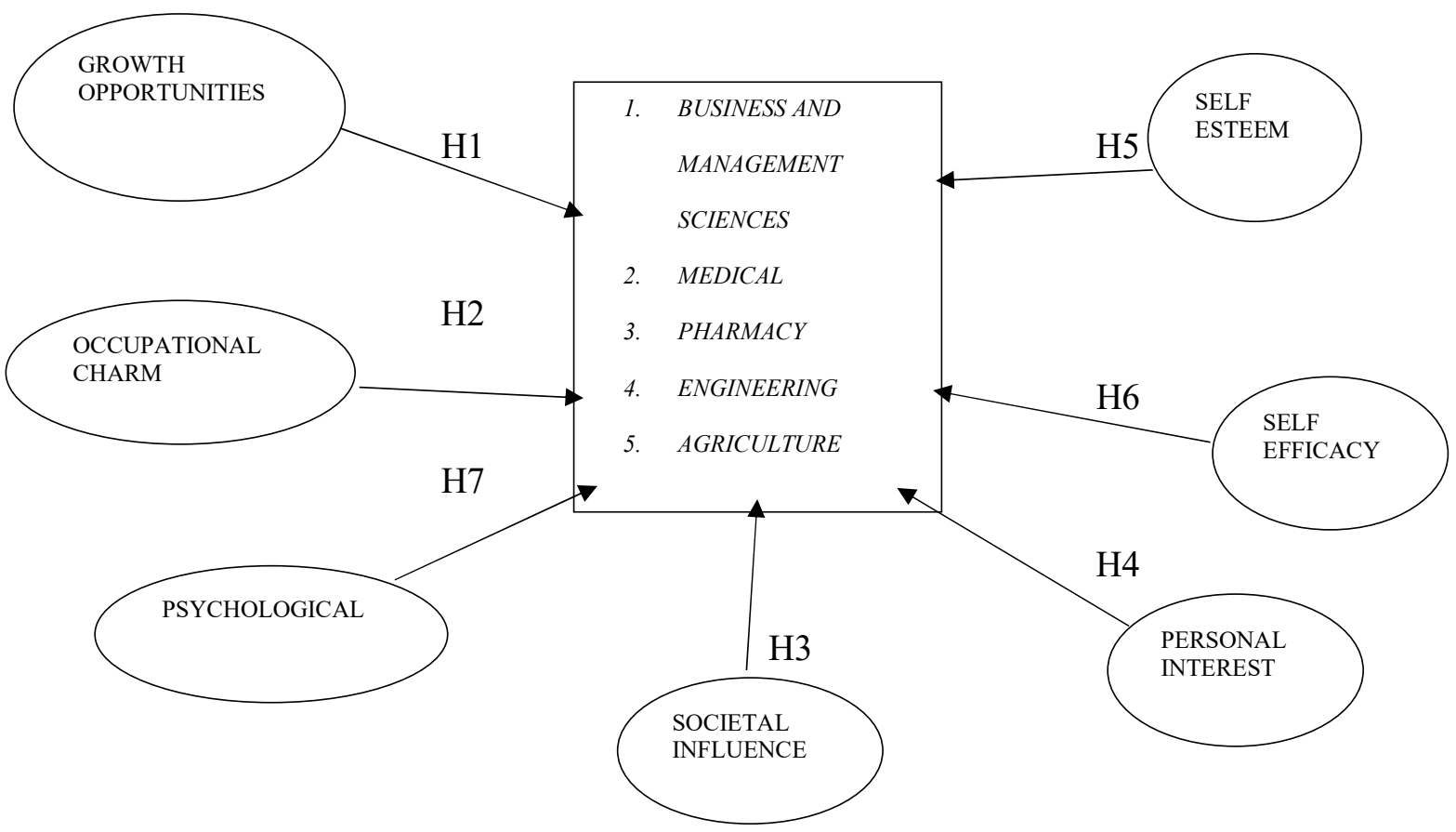

Figure 1. Theoretical framework

\subsection{Career theories}

According to the social cognitive theory, individuals who wants to maintain their own career behavior so three variables are required which is self-efficacy beliefs, outcome expectations and personal goals (Lent \& Brown, 1996). Self-efficacy means the individual own beliefs and judgment on their skills and capabilities to perform certain task and activities which may include academic and work tasks (Hackett, Brown, 1994). If the individual wants to attain self-efficacy beliefs, there are four sources to acquire the self-efficacy which includes personal accomplishments, vicarious learning, social persuasion, psychological states (Lent \& Brown, 1996). Self-efficacy measures on performance domain so personal performance accomplishments have high impact on self-efficacy (Lent \& Brown, 1996). Outcomes expectation are individual beliefs after the performance of the specific tasks, it also include the individual behavior about the consequences and results of the performance for example the outcome expectation of career paths can only be derived through direct or indirect learning experiences (Lent \& Brown, 1996). Personal goals plays an important role in career selection decision. It involves the personal interest of an individual in a certain task in order to receive a positive outcome. According social cognitive theory self-efficacy and outcome expectations are reasons to which goals of the individual affected (Lent \& Brown, 1996).

Another valuable theory for career development is career Anchors theory which is introduced by (E. Schein, 1978) in 1978. According to this theory "career Anchor" is the individual values, needs and abilities (E. H. Schein, 2001). Most of the people are not aware of their career anchor, it only be gain by experiences either life or occupational. To reflect the people needs, values and motives (E. H. Schein, 2001) gave five career anchors and later on he extended their five anchors to eight these are I, service or dedication to cause ii, security or stability iii, pure challenge iv, general managerial competence $\mathrm{v}$, technical competence vi, autonomy/independence vii, entrepreneurial creativity viii, life styles (E. H. Schein, 2001).

\subsection{Variables}

Independent variables are:

1. Growth opportunities (students give priority to those professions that have growth opportunities for further higher studies, on/off job training, international exposure and knowledge/skills)

2. Occupational charm (students prefer professions that have charm like handsome starting salary, flexible job environment, job vacancies and job security)

3. Societal influence (selection of profession affects by parents, teachers, siblings, friends, guardians) 
4. Personal interest (personal interest plays a major role in shaping the career decisions, it includes selfinterest, excitement, childhood interest, thirst of learning)

5. Self-efficacy (student's belief on his/her abilities, decisions. They focused on positive outcomes on their profession selection decision)

6. Self-esteem (those people who wants higher position, status, prestige, high influence on society so their career choices affects)

7. Psychological effects (sometimes people emotionally attached with specific occupations also they think that their quality of life associated with the profession they will select)

Dependent variables (Carrier choices) are:

1. Business and administrative sciences

2. Medical

3. Pharmacy

4. Engineering

5. Agriculture

3.3 Research hypothesis

H1: Growth opportunities affect the selection of career choices for above mentioned professions.

$\mathrm{H} 2$ : Occupational charm affect the selection of career choices for above mentioned professions.

H3: Societal influence affect the selection of career choices for above mentioned professions.

H4: Personal interest affect the selection of career choices for above mentioned professions.

H5: self-esteem affect the selection of career choices for above mentioned professions.

H6: self-efficacy affect the selection of career choices for above mentioned professions.

H7: psychological factor affect the selection of career choices for above mentioned professions.

\section{Research Methodology \\ 4.1 Data collection}

To attain the aim of this study, three well reputed and specialized institutions in each discipline were selected these institutions are: university of Karachi (uok), Dow medical university and health sciences (DUHMS) and NED university. For the management and administrative sciences profession data were form the department of Karachi university business school (KUBS), for pharmacy profession data were collected form the department of pharmaceutical sciences in university of Karachi, for agriculture profession data were collected from the department of agriculture and agribusiness management in university of Karachi, for engineering profession data were collected from NED university and for medical profession data were collected from Dow medical university and health sciences.

\subsection{Scale development}

For this study Survey questionnaire was developed consisted on seven independent variables influencing career choice decisions, however modification were also made to achieve the objectives of the study and to accurately measure the construct. The target audience were the students who currently enrolled in the following professions: management sciences, medical, pharmacy, engineering and agriculture. Valuable sample of 523 were collected from students through convenience sampling. All responses were measured in a Likertscale 1 , strongly agree 2 , agree 3 , disagree 4 , strongly disagree. The content of the questionnaire was based on the variables taken from an extensive literature review of different authors (Agarwala, 2008b), (M Rosenberg Acceptance and commitment therapy., 1965), (Nauman, 2014), (Smith, n.d.), (Ciarrochi \& Bilich, n.d.), (Taylor \& Popma, 1990), (Carpenter \& foster, 1977), (Fejgin, Ephraty, \& Ben-Sira, 1995), (Dick \& Rallis, 2006).

\subsection{Software}

Smart PLS software used for data analysis and PROMETHEE used for evaluations of professions. 


\subsection{Descriptive Statistics}

Table 1. (Descriptive statistics)

\begin{tabular}{|c|l|l|}
\hline & um & ean \\
\hline Male & 85 & 35 \\
\hline Female & 37 & 64 \\
\hline business & & 19 \\
\hline administration & 9 & 19 \\
\hline Pharmacy & 0 & 17 \\
\hline Medical & 44 & 28 \\
\hline Engineering & 2 & 18 \\
\hline Agriculture & & 19 \\
\hline
\end{tabular}

The above table shows descriptive statistics in which 185 males and 337 females were participated. In business administration there were 99 number of respondents, in pharmacy there were 90 number of respondents, in medical there were 144 number of respondents and in agriculture there were 98 number of respondents participated.

\subsection{Multi-criteria profession Ranking}

Profession selection is the difficult decision for students because it involves many criteria that must be taken into consideration. Since many factors that we mentioned in this paper can affect and molds the profession selection decision of students. Because of the numerous criteria exist, this issue can come under the multi-criteria decision making problem (MCDM). Many techniques had been developed to solve the multi-criteria decision (MCDM) problem. MCDM methods are now extensively used to select the best and appropriate option among many alternatives. Different techniques used for MCDM methods have different advantages that ranked each factor/criteria from best to worse one. According to our study we used PROMETHEE to rank our five different mentioned professions.

\subsection{Ranking methodology}

PROMETHEE I: is also called the partial ranking. It can be obtained if the leaving flow of alternative (a) is better or greater than the leaving flow of alternative (b) and the entering flow of (a) is smaller or less than the entering flow of (b), shows that (a) is superior to alternative (b) (Albadvi, Chaharsooghi, \& Esfahanipour, 2006). This partial ranking allows indifference which means that in some cases alternatives are incomparable or the leaving and entering flow is equal for example if the leaving flow shows (a) is better than (b) and entering flow shows reverse (Albadvi et al., 2006).

PROMETHEE II: ranking is the complete ranking of alternatives, it is based on net preference flow (leaving minus entering flow). The alternative whose net flow is higher consider to others one (Albadvi et al., 2006). In our study we take five professions as an evaluations or alternatives against the following criteria: growth opportunities, occupational charm, self-esteem, societal influence, personal interest, self-efficacy and psychological effects.

\subsection{Applying promethee}

First of all evaluation matrix is formed according to what scores each profession possess. All the criteria have same importance so weights of the criteria has equal. Preference function is verified by (Brans $\&$ De Smet, 2016) for likert scale, type 1 usual function is selected for all criteria so no need to specify any parameters. Threshold types for all criteria has selected as absolute. 


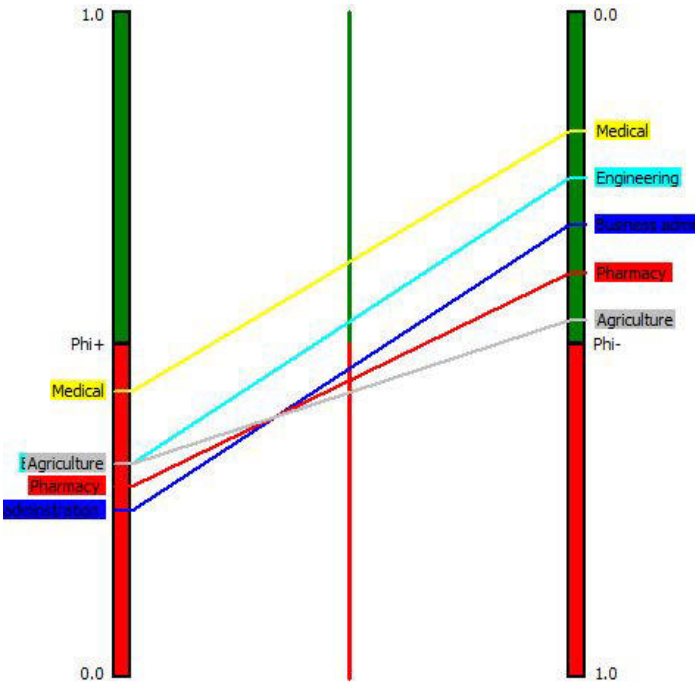

Figure 2

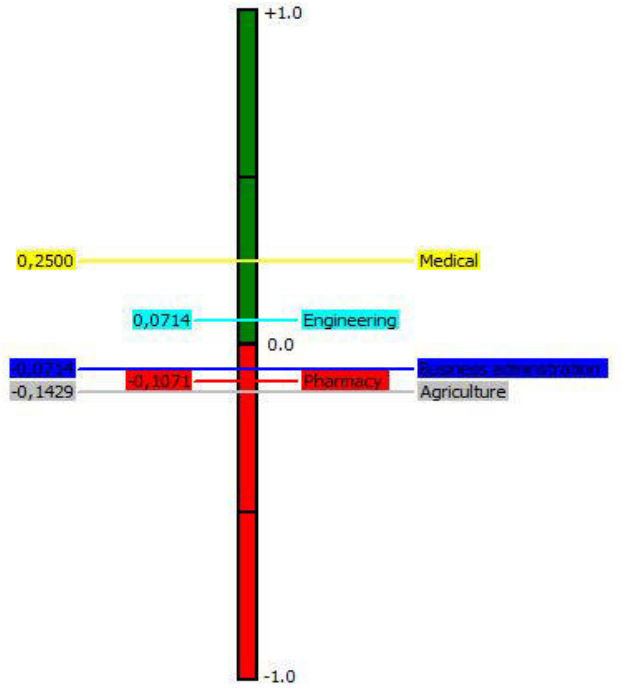

figure 3

In figure 2 partial ranking medical profession shows at top due to high positive and low negative flows, other professions like business administration, pharmacy and agriculture are incomparable due to low positive flows and high negative flows so PROMETHEE I shows partial ranking of professions and it is not able to provide sufficient information about the best profession. PROMETHEE II shows complete ranking of profession which can be seen in figure 3 that professions are ranked according to the net preference flows and due to this medical profession is superior among other professions after that engineering profession have ranked 2, business administration have ranked 3, pharmacy ranked 4 and agriculture have ranked 5 because of low negative net preference flow.

\subsection{Structural equation modelling}

To test the study hypothesis we have used the structural equation model (SEM) whereas the testing has been gone through Smart PLS software. Moreover, to evaluate the indirect and direct effects of all the constructs the testing was done. The use of (SEM) structural equation model has been observed to be a foremost procedure that has been used below different regression models and methods (Baron \& Kenny, 1986).

\subsection{Composite reliability and Chronbach's alpha}

Composite reliability and Chronbach's Alpha is used to show reliability of construct. Its value should be greater than 0.7. average variance extracted is the degrees which shows actuality or support the convergent validity (Square, Approach, Surienty, Lo, \& Natasha, 2013). As per (Hair, Hult, \& Ringle, 2017) AVE value should be greater than 0.5 . Table $2,3,4,5$ and 6 shows the reliability for each profession.

Table 2. (Reliability of business and management sciences)

\begin{tabular}{|c|c|c|c|c|}
\hline & $\begin{array}{c}\text { Cronbac } \\
\text { h's Alpha }\end{array}$ & rho_A & $\begin{array}{c}\text { Comp } \\
\text { osite } \\
\text { Reliability }\end{array}$ & $\begin{array}{l}\text { Average } \\
\text { Variance } \\
\text { Extracted } \\
\text { (AVE) }\end{array}$ \\
\hline $\begin{array}{c}\text { business and } \\
\text { management sciences }\end{array}$ & 1.000 & 1.000 & 1.000 & 1.000 \\
\hline Growth & 0.609 & 0.776 & 0.824 & 0.703 \\
\hline occupational charm & 0.742 & 0.799 & 0.828 & 0.548 \\
\hline Personal & 0.721 & 0.905 & 0.814 & 0.528 \\
\hline self esteem & 0.726 & 0.741 & 0.879 & 0.784 \\
\hline Societal & 0.764 & 0.940 & 0.849 & 0.653 \\
\hline
\end{tabular}


Table 3. (Reliability of medical)

\begin{tabular}{|c|c|c|c|c|}
\hline & s Alpha ${ }^{\text {Cronbach' }}$ & rho_A & $\begin{array}{l}\text { Compos } \\
\text { ite Reliability }\end{array}$ & \begin{tabular}{l}
\multicolumn{2}{c}{ Average } \\
Variance Extracted \\
(AVE)
\end{tabular} \\
\hline Medical & 1.000 & 1.000 & 1.000 & 1.000 \\
\hline Growth & 0.706 & 0.730 & 0.812 & 0.521 \\
\hline occupation & 0.716 & -0.331 & 0.541 & 0.379 \\
\hline $\begin{array}{l}\text { personal } \\
\text { interest }\end{array}$ & 0.759 & 0.779 & 0.845 & 0.578 \\
\hline efficacy & 0.696 & 0.758 & 0.827 & 0.617 \\
\hline $\begin{array}{ll}\text { self } \\
\text { esteem }\end{array}$ & 0.724 & 0.740 & 0.820 & 0.534 \\
\hline societal & 0.753 & 1.126 & 0.876 & 0.781 \\
\hline
\end{tabular}

Table 4. (Reliability of pharmacy)

\begin{tabular}{|c|r|r|r|c|}
\hline & $\begin{array}{r}\text { Cron } \\
\text { bach's Alpha }\end{array}$ & A & \multicolumn{1}{|c|}{$\begin{array}{l}\text { Comp } \\
\text { osite } \\
\text { Reliability }\end{array}$} & $\begin{array}{l}\text { Average } \\
\text { Variance } \\
\text { Extracted (AVE) }\end{array}$ \\
\hline Pharmacy & 1.000 & 1.000 & 1.000 & 1.000 \\
\hline $\begin{array}{c}\text { growth } \\
\text { opportunities }\end{array}$ & 0.507 & 0.604 & 0.791 & 0.658 \\
\hline $\begin{array}{c}\text { occupational } \\
\text { charm }\end{array}$ & 0.697 & 0.764 & 0.823 & 0.610 \\
\hline personal interest & 0.738 & 0.818 & 0.843 & 0.643 \\
\hline Psycho & 1.000 & 1.000 & 1.000 & 1.000 \\
\hline self-efficacy & 1.000 & 1.000 & 1.000 & 1.000 \\
\hline self esteem & 0.725 & 0.790 & 0.838 & 0.635 \\
\hline societal influence & 0.776 & 0.789 & 0.869 & 0.689 \\
\hline
\end{tabular}

Table 5. (Reliability of engineering)

\begin{tabular}{|c|c|c|c|c|}
\hline & $\begin{array}{c}\text { Cronbach } \\
\text { 's Alpha }\end{array}$ & rho_A & \multicolumn{1}{c|}{ Comp } & $\begin{array}{l}\text { Avera } \\
\text { Variance } \\
\text { ge } \\
\text { Extracted } \\
\text { (AVE) }\end{array}$ \\
\hline Engineering & 1.000 & 1.000 & 1.000 & 1.000 \\
\hline $\begin{array}{c}\text { growth } \\
\text { opportunities }\end{array}$ & 0.609 & 0.735 & 0.827 & 0.707 \\
\hline $\begin{array}{c}\text { occupational } \\
\text { charm }\end{array}$ & 0.742 & 0.085 & 0.723 & 0.422 \\
\hline Psycho & 1.000 & 1.000 & 1.000 & 1.000 \\
\hline self-efficacy & 0.752 & 0.803 & 0.838 & 0.566 \\
\hline self esteem & 0.725 & 0.805 & 0.836 & 0.631 \\
\hline $\begin{array}{c}\text { societal } \\
\text { influence }\end{array}$ & 0.799 & 0.861 & 0.866 & 0.619 \\
\hline
\end{tabular}


Table 6. (Reliability of agriculture)

\begin{tabular}{|c|c|c|c|c|}
\hline & $\begin{array}{c}\text { Cronb } \\
\text { ach's Alpha }\end{array}$ & rho_A & $\begin{array}{c}\text { Compos } \\
\text { ite Reliability } \\
\text { Variance } \\
\text { Extracted } \\
\text { (AVE) }\end{array}$ \\
\hline Agriculture & 1.000 & 1.000 & 1.000 & 1.000 \\
\hline $\begin{array}{c}\text { growth } \\
\text { opportunities }\end{array}$ & 0.672 & 0.686 & 0.818 & 0.599 \\
\hline $\begin{array}{c}\text { occupational } \\
\text { charm }\end{array}$ & 0.716 & 0.736 & 0.839 & 0.636 \\
\hline personal interest & 0.772 & 0.828 & 0.846 & 0.580 \\
\hline Psycho & 0.650 & 0.736 & 0.800 & 0.577 \\
\hline self-efficacy & 0.734 & 0.735 & 0.833 & 0.555 \\
\hline self esteem & 0.766 & 0.797 & 0.850 & 0.587 \\
\hline Societal & 0.734 & 0.285 & 0.775 & 0.547 \\
\hline
\end{tabular}

The reliability of management sciences profession are meeting the threshold value except one variable which is growth but the composite reliability shows reliable results for that as shown in table 2 . The reliability of variables in medical profession also above the threshold value as shown in table 3 . The reliability of variables in pharmacy profession also shows above threshold value except growth opportunities and occupational charm but the composite reliability shows reliable results as shown in table 4 . The composite reliability of engineering and agriculture profession also shows reliable results as shown in table 5, 6 respectively.

\subsection{Factor loadings significant}

Below is the mentioned table of (CFA) confirmatory factor analysis with the loadings. Construct with the loading of .5 are consider as strong loading variables whereas the constructs with the loading of below .5 are considered as less are better to be removed from the table.

Table 7. (Factors loadings)

\begin{tabular}{|c|c|c|c|c|}
\hline \multirow{2}{*}{ Business and management sciences } & Constructs & $\begin{array}{ll} & \text { Item } \\
\text { loading } & \\
\end{array}$ & $\begin{array}{ll} & \mathrm{T} \\
\text {-value } & \end{array}$ & $\begin{array}{ll} & P \\
\text {-Value } & \\
\end{array}$ \\
\hline & $\begin{array}{l}\text { G } 13 \\
\text { G } 9 \\
\end{array}$ & $\begin{array}{r}0.933 \\
0.733 \\
\end{array}$ & 0.449 & 0.327 \\
\hline & $\begin{array}{lll} & 14 \\
\text { O } & 15 \\
\text { O } & 16 \\
\text { O } & 17 \\
\end{array}$ & $\begin{array}{l}0.702 \\
0.841 \\
0.658 \\
0.746 \\
\end{array}$ & 1.182 & 0.119 \\
\hline & $\begin{array}{l}\text { P.I } 28 \\
\text { P.I } 29 \\
\text { P.I } 30 \\
\text { P.I } 31 \\
\end{array}$ & $\begin{array}{l}0.89 \\
0.729 \\
0.568 \\
0.681 \\
\end{array}$ & 2.721 & 0.003 \\
\hline & $\begin{array}{l}\text { S.E } 19 \\
\text { S.E } 20\end{array}$ & $\begin{array}{l}0.864 \\
0.906\end{array}$ & 1.981 & 0.024 \\
\hline & $\begin{array}{l}\text { S.I } 24 \\
\text { S.I } 25 \\
\text { S.I } 26 \\
\end{array}$ & $\begin{array}{l}0.898 \\
0.775 \\
0.74 \\
\end{array}$ & 2.937 & 0.002 \\
\hline \multirow[t]{6}{*}{ MEDICAL } & $\begin{array}{l}\text { G } 11 \\
\text { G } 12 \\
\text { G } 13 \\
\text { G } 9\end{array}$ & $\begin{array}{l}0.719 \\
0.621 \\
0.804 \\
0.732 \\
\end{array}$ & 1.440 & 0.075 \\
\hline & $\begin{array}{ll}\text { O } 14 \\
\text { O } 15 \\
\text { O } 16\end{array}$ & $\begin{array}{l}0.920 \\
0.54 \\
0.020 \\
\end{array}$ & 0.448 & 0.327 \\
\hline & $\begin{array}{l}\text { P.I } 28 \\
\text { P.1 } 29 \\
\text { P.I } 30 \\
\text { P.I } 32 \\
\end{array}$ & $\begin{array}{l}0.722 \\
0.802 \\
0.714 \\
0.797 \\
\end{array}$ & 1.475 & 0.070 \\
\hline & $\begin{array}{l}\text { S.EFF } 34 \\
\text { S.EFF } 36 \\
\text { S.EFF } 37 \\
\end{array}$ & $\begin{array}{l}0.719 \\
0.876 \\
0.753 \\
\end{array}$ & 3.136 & 0.001 \\
\hline & $\begin{array}{l}\text { S.E } 19 \\
\text { S.E } 20 \\
\text { S.E } 22 \\
\text { S.E } 23 \\
\end{array}$ & $\begin{array}{l}0.692 \\
0.678 \\
0.822 \\
0.722 \\
\end{array}$ & 2.099 & 0.018 \\
\hline & $\begin{array}{l}\text { S.I } 25 \\
\text { S.I } 26 \\
\end{array}$ & $\begin{array}{l}0.963 \\
0.796 \\
\end{array}$ & 1.264 & 0.103 \\
\hline \multirow[t]{2}{*}{ PHARMACY } & $\begin{array}{l}\text { G } 10 \\
\text { G } 11 \\
\end{array}$ & $\begin{array}{l}0.699 \\
0.910 \\
\end{array}$ & 2.625 & 0.004 \\
\hline & $\begin{array}{l}\text { O } 16 \\
\text { O } 17 \\
\text { O } 18\end{array}$ & $\begin{array}{l}0.764 \\
0.870 \\
0.700\end{array}$ & 1.447 & 0.074 \\
\hline
\end{tabular}




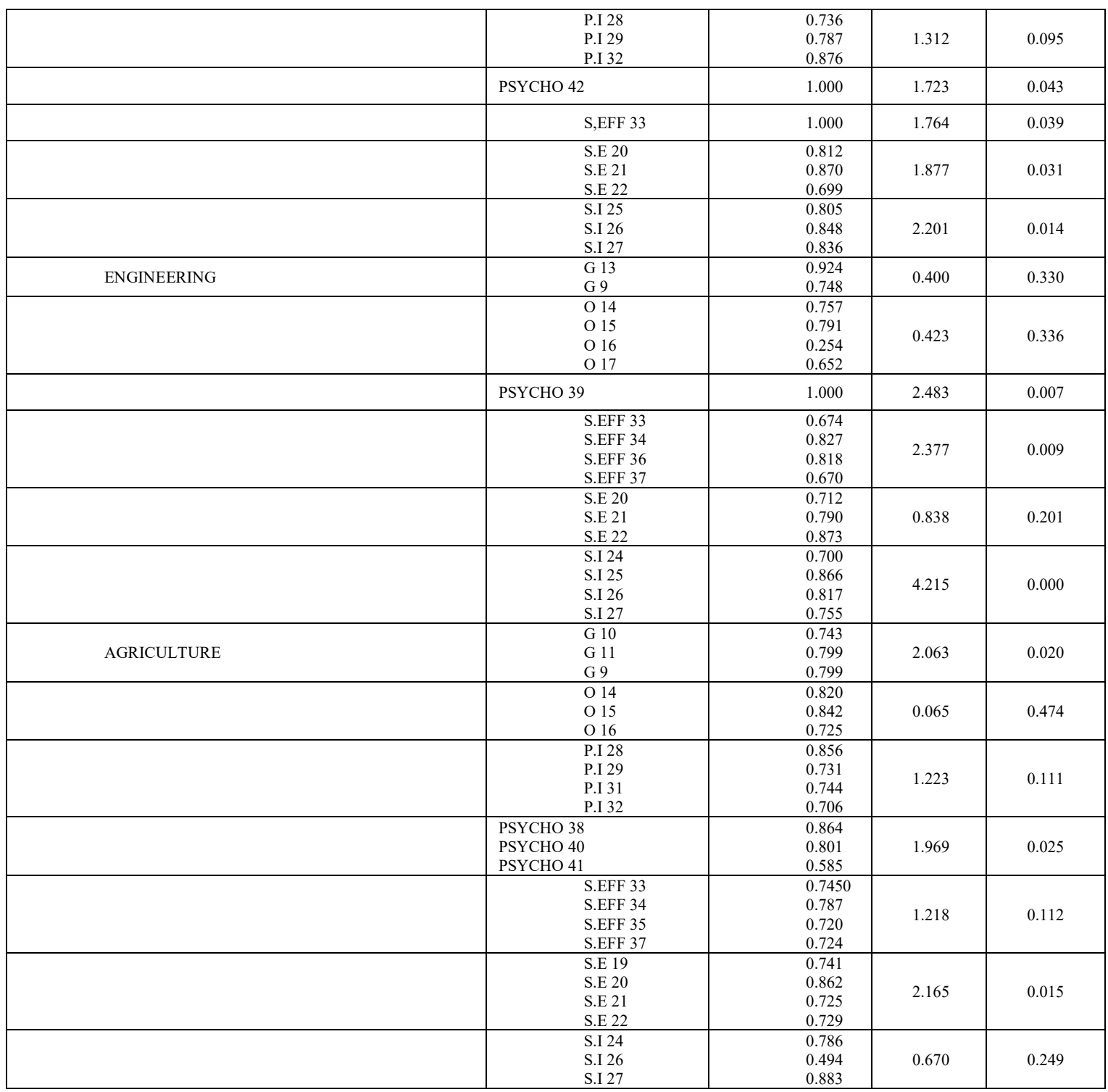

\subsection{Measuring the model fit}

Standardized Root Mean Square Residual defined as 'the differences between the observed correlation and predicted correlation of the variables constructs"' (Henseler, Hubona, \& Ash, 2016). So SRMR allows measuring the average degree of the differences between observed and expected correlation as an absolute measure of model fit criterion. Its value should be less than 0.10 which consider a good fit value (Hu \& Bentler, 1999). Following are the SRMR value for each model which is lesser than threshold value shows goodness of fit of the models in table 8, 9, 10, 11 and 12 .

Table 8. (Model fit of business and management sciences)

\begin{tabular}{|c|c|c|}
\hline $\begin{array}{c}\text { Business and management } \\
\text { sciences }\end{array}$ & Saturated & Estimated \\
\hline SRMR & 0.077 & 0.077 \\
\hline d_ULS & 0.813 & 0.813 \\
\hline d_G & 0.290 & 0.290 \\
\hline Chi-Square & 949.428 & 949.428 \\
\hline NFI & 0.577 & 0.577 \\
\hline
\end{tabular}


Table 9. (Model fit of medical)

\begin{tabular}{|l|l|l|}
\hline Fit Summary & & \\
\hline Medical & Saturated Model & Estimated Model \\
\hline SRMR & 0.098 & 0.098 \\
\hline d_ULS & 2.209 & 2.209 \\
\hline d_G & 0.445 & 0.445 \\
\hline Chi-Square & $1,291.401$ & $1,291.401$ \\
\hline NFI & 0.617 & 0.617 \\
\hline
\end{tabular}

Table 10. (Model fit of pharmacy)

\begin{tabular}{|l|l|l|}
\hline Fit Summary & & \\
\hline Pharmacy & Saturated Model & Estimated Model \\
\hline SRMR & 0.074 & 0.074 \\
\hline d_ULS & 0.834 & 0.834 \\
\hline d_G & 0.279 & 0.279 \\
\hline Chi-Square & 905.576 & 905.576 \\
\hline NFI & 0.614 & 0.614 \\
\hline
\end{tabular}

Table 11. (Model fit of engineering)

\begin{tabular}{|l|l|l|}
\hline Fit Summary & & \\
\hline Engineering & Saturated Model & Estimated Model \\
\hline SRMR & 0.079 & 0.079 \\
\hline d_ULS & 1.175 & 1.175 \\
\hline d_G & 0.300 & 0.300 \\
\hline Chi-Square & 899.540 & 899.540 \\
\hline NFI & 0.673 & 0.673 \\
\hline
\end{tabular}

Table 12. (Model fit of agriculture)

\begin{tabular}{|c|l|l|}
\hline $\begin{array}{c}\text { Fit } \\
\text { Summary }\end{array}$ & & \\
\hline Agriculture & Saturated Model & Estimated Model \\
\hline SRMR & 0.073 & 0.073 \\
\hline d_ULS & 1.750 & 1.750 \\
\hline d_G & 0.483 & 0.483 \\
\hline Chi-Square & $1,493.266$ & $1,493.266$ \\
\hline NFI & 0.636 & 0.636 \\
\hline
\end{tabular}

\section{Findings}

\subsection{Bootstrapping}

Bootstrapping is one of the key steps in PLS-SEM which provide the information of stability of coefficient estimates. In this process a large number of sub samples are drawn from the original sample with replacement (Hair et al., 2017). After running the bootstrap routine, smart PLS show T-values for structural model estimates derived from the bootstrapping procedure. The results of path coefficients for all the hypothesis are shown in the following tables. The $\mathrm{T}$-value greater than $1.96(\mathrm{p}<0.05)$ shows the relationship is significant at $95 \%$ confidence interval $(\alpha=0.05)$. 
Table 13. (P-values for business and management sciences)

\begin{tabular}{|c|c|c|c|c|c|}
\hline Mean, STDEV, T-Values, P-Values & & & & & \\
\hline & $\begin{array}{r}\text { Origi } \\
\text { nal Sample }(\mathrm{O})\end{array}$ & $\begin{array}{l}\text { Sam } \\
\text { ple Mean (M) }\end{array}$ & $\begin{array}{lr} & \text { Standa } \\
\text { rd } & \text { Deviation } \\
(\mathrm{STDEV}) & \\
\end{array}$ & $\begin{array}{l}\text { Ttatistics } \\
(|\mathrm{O} / \mathrm{STDEV}|)\end{array}$ & Values \\
\hline $\begin{array}{l}\text { growth }->\text { business and management } \\
\text { sciences }\end{array}$ & 0.021 & 0.006 & 0.048 & 0.449 & 0.327 \\
\hline $\begin{array}{l}\text { occupational charm }->\text { business and } \\
\text { management sciences }\end{array}$ & -0.052 & -0.073 & 0.044 & 1.182 & 0.119 \\
\hline $\begin{array}{rrrr}\text { personal } & -> & \text { business } & \text { and } \\
\text { management sciences } & & & \\
\end{array}$ & -0.118 & -0.122 & 0.043 & 2.721 & 0.003 \\
\hline $\begin{array}{llll}\text { self-esteem } & -> & \text { business } & \text { and } \\
\text { management sciences } & & & \\
\end{array}$ & -0.088 & -0.078 & 0.045 & 1.981 & 0.024 \\
\hline $\begin{array}{l}\text { societal }->\text { business and management } \\
\text { sciences }\end{array}$ & 0.138 & 0.147 & 0.047 & 2.937 & 0.002 \\
\hline
\end{tabular}

Table 14. (P-values for medical)

\begin{tabular}{|c|c|c|c|c|c|}
\hline \multicolumn{6}{|c|}{ Mean, STDEV, T-Values, P-Values } \\
\hline & \begin{tabular}{|l|} 
Original \\
Sample $(\mathrm{O})$ \\
\end{tabular} & $\begin{array}{r}\text { Samp } \\
\text { le Mean (M) }\end{array}$ & $\begin{array}{r}\text { Standard } \\
\text { Deviation (STDEV) } \\
\end{array}$ & $\begin{array}{r}\text { T Statistics } \\
(|\mathrm{O} / \mathrm{STDEV}|)\end{array}$ & Values \\
\hline $\begin{array}{lll} & \text { growth } & -> \\
\text { Medical } & & \\
\end{array}$ & -0.064 & -0.073 & 0.045 & 1.440 & .075 \\
\hline $\begin{array}{lll} & \text { occupation } & -> \\
\text { Medical } & \end{array}$ & -0.038 & -0.010 & 0.085 & 0.448 & .327 \\
\hline $\begin{aligned} & \text { personal } \\
& \text { interest }->\text { Medical }\end{aligned}$ & 0.086 & 0.056 & 0.058 & 1.475 & .070 \\
\hline $\begin{array}{ll}\text { Medical } & \text { self-efficacy -> } \\
\end{array}$ & -0.142 & -0.131 & 0.045 & 3.136 & .001 \\
\hline $\begin{array}{lll} & \text { self-esteem -> } \\
\text { Medical } & \\
\end{array}$ & -0.117 & -0.111 & 0.056 & 2.099 & .018 \\
\hline $\begin{array}{ll}\text { Medical } & \text { societal } \\
\end{array}$ & 0.059 & 0.066 & 0.046 & 1.264 & .103 \\
\hline
\end{tabular}

Table 15. (P-values for pharmacy)

\begin{tabular}{|c|c|c|c|c|c|c|}
\hline \multicolumn{7}{|c|}{ Mean, STDEV, T-Values, P-Values } \\
\hline & $\begin{array}{l}\text { Origin } \\
\text { al Sample }(\mathrm{O})\end{array}$ & $\begin{array}{l}\text { Samp } \\
\text { le Mean (M) }\end{array}$ & $\begin{array}{l}\text { Standard } \\
\text { Deviation } \\
\text { (STDEV) }\end{array}$ & \begin{tabular}{l}
\multicolumn{1}{c}{$T$} \\
Statistics \\
$(|\mathrm{O} / \mathrm{STDEV}|)$
\end{tabular} & Values & $\mathrm{P}$ \\
\hline $\begin{array}{lll}\text { growth } & \text { Opportunities } & -> \\
\text { Pharmacy } & & \\
\end{array}$ & -0.119 & -0.125 & 0.045 & 2.625 & 04 & 0.0 \\
\hline occupational charm -> Pharmacy & -0.072 & -0.085 & 0.050 & 1.447 & 74 & 0.0 \\
\hline personal interest -> Pharmacy & 0.092 & 0.093 & 0.071 & 1.312 & 95 & 0.0 \\
\hline psycho -> Pharmacy & -0.079 & -0.072 & 0.046 & 1.723 & 43 & 0.0 \\
\hline self-efficacy -> Pharmacy & 0.078 & 0.084 & 0.044 & 1.764 & 39 & 0.0 \\
\hline self-esteem -> Pharmacy & -0.078 & -0.080 & 0.041 & 1.877 & 31 & 0.0 \\
\hline
\end{tabular}

Table 16. (P-values for engineering)

\begin{tabular}{|c|c|c|c|c|c|}
\hline \multicolumn{6}{|c|}{ Mean, STDEV, T-Values, P-Values } \\
\hline & 1 Sample $(O){ }^{\text {Origina }}$ & $\begin{array}{l}\text { Sam } \\
\text { ple Mean (M) }\end{array}$ & $\begin{array}{r}\text { Standard } \\
\text { Deviation (STDEV) }\end{array}$ & $\begin{array}{r}\text { T Statistics } \\
(|\mathrm{O} / \mathrm{STDEV}|)\end{array}$ & Values \\
\hline $\begin{array}{l}\text { growth opportunities - } \\
>\text { Engineering }\end{array}$ & 0.022 & 0.028 & 0.049 & 0.440 & .330 \\
\hline Engineering occupational charm -> & 0.037 & 0.028 & 0.086 & 0.423 & .336 \\
\hline psycho -> Engineering & 0.109 & 0.107 & 0.044 & 2.483 & .007 \\
\hline $\begin{array}{ll}\text { self-efficacy } & -> \\
\text { Engineering } & \end{array}$ & 0.121 & 0.121 & 0.051 & 2.377 & .009 \\
\hline $\begin{array}{ll}\text { Engineering } & \text { self-esteem } \\
\text { E }\end{array}$ & 0.046 & 0.049 & 0.055 & 0.838 & .201 \\
\hline $\begin{array}{lll}\text { societal influence } & -> \\
\text { Engineering } & & \\
\end{array}$ & -0.182 & -0.186 & 0.043 & 4.215 & .000 \\
\hline
\end{tabular}

Table 17. (P-values for agriculture) 


\begin{tabular}{|c|c|c|c|c|c|}
\hline & $\begin{array}{l}\text { Origin } \\
\text { al Sample }(\mathrm{O}) \\
\end{array}$ & $\begin{array}{l}\text { Sam } \\
\text { ple Mean (M) } \\
\end{array}$ & $\begin{array}{r}\text { Standard } \\
\text { Deviation (STDEV) } \\
\end{array}$ & $\begin{array}{l}\text { T Statistics } \\
(|\mathrm{O} / \mathrm{STDEV}|) \\
\end{array}$ & Values \\
\hline $\begin{array}{l}\text { growth Opportunities } \\
\text {-> Agriculture }\end{array}$ & 0.093 & 0.089 & 0.045 & 2.063 & 0.020 \\
\hline $\begin{array}{l}\text { occupational charm - } \\
>\text { Agriculture }\end{array}$ & -0.003 & 0.000 & 0.048 & 0.065 & 0.474 \\
\hline $\begin{array}{l}\text { personal interest }-> \\
\text { Agriculture }\end{array}$ & 0.056 & 0.055 & 0.046 & 1.223 & 0.111 \\
\hline \begin{tabular}{ll}
\multicolumn{1}{c}{ psycho } & $->$ \\
Agriculture &
\end{tabular} & 0.118 & 0.109 & 0.060 & 1.969 & 0.025 \\
\hline $\begin{array}{ll}\text { self-efficacy } & -> \\
\text { Agriculture } & \end{array}$ & -0.063 & -0.033 & 0.051 & 1.218 & 0.112 \\
\hline Agriculture & 0.122 & 0.122 & 0.056 & 2.165 & 0.015 \\
\hline $\begin{array}{ll}\text { Agriculture }^{\text {societal }} & -> \\
\end{array}$ & 0.047 & 0.051 & 0.069 & 0.678 & 0.249 \\
\hline
\end{tabular}

\subsection{Path Diagrams}

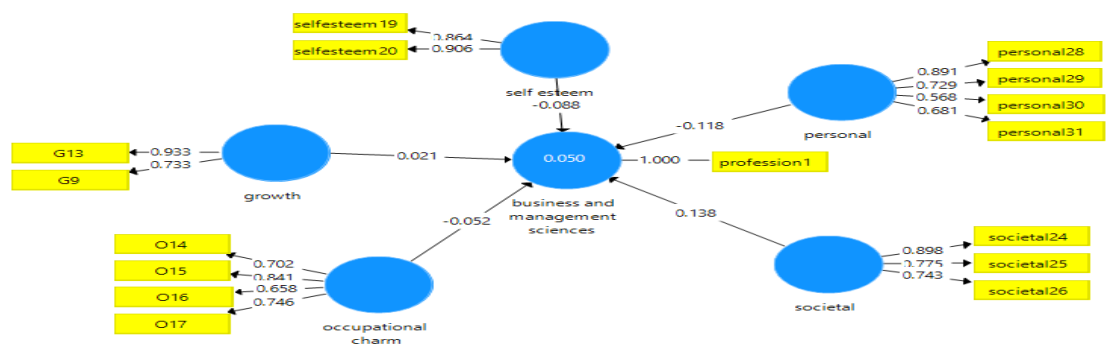

Figure 4. (Path diagram for business and management sciences)

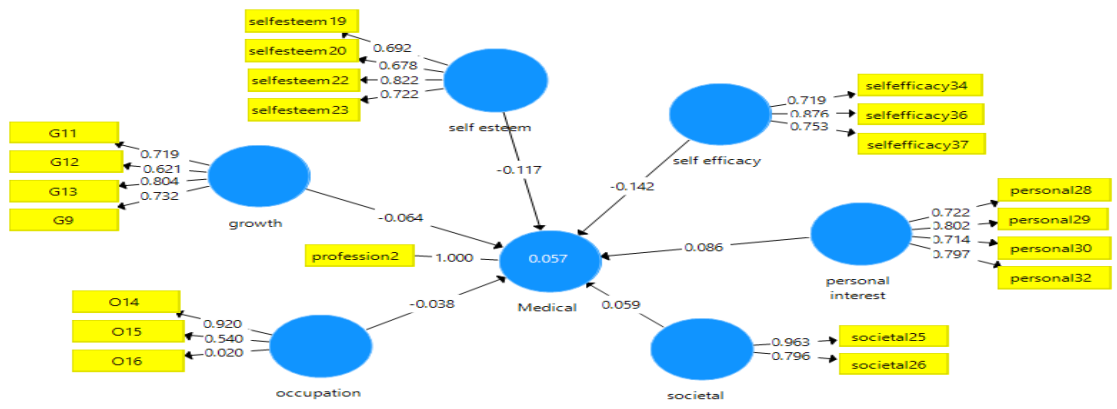

Figure 5. (Path diagram for medical)

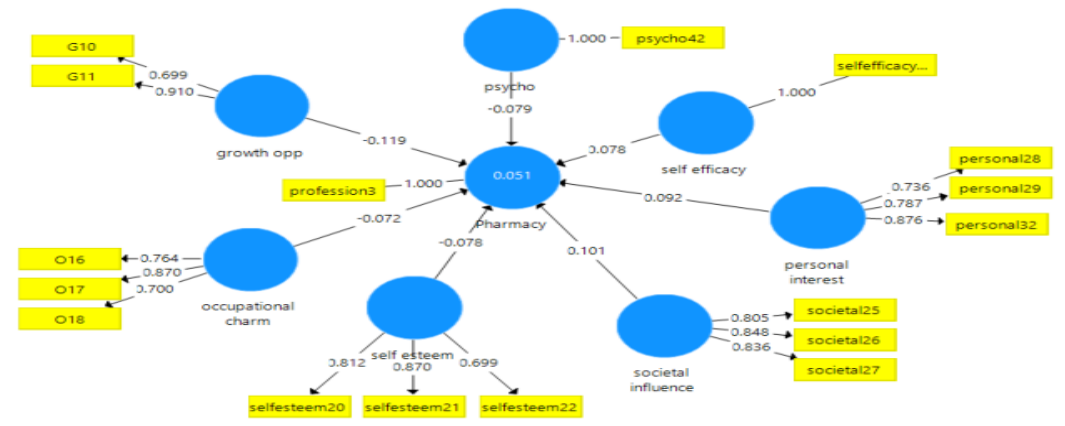

Figure 6. (Path diagram for pharmacy) 


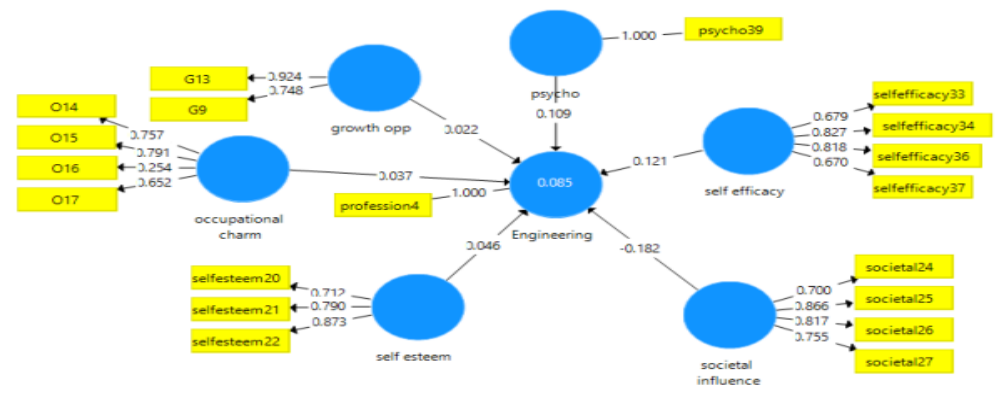

Figure 7. (Path diagram for engineering)

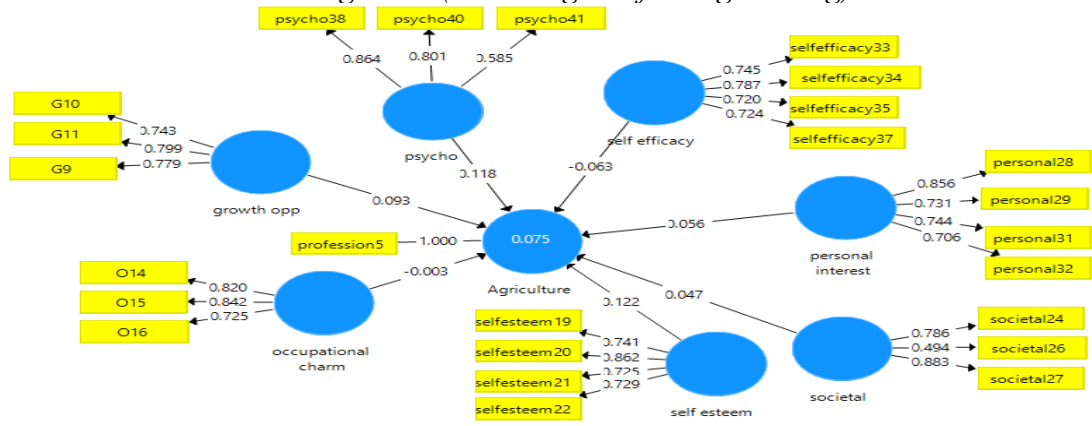

Figure 8. (Path diagram for agriculture)

SEM structural model for five professions are shown in figure 4, 5, 6, 7 and 8 . The relationship between variables shown in inner model and factor loadings of each indicator shown in outer model. High outer loadings on a construct indicate the associated indicators have much in common, which is captured by the construct (Hair et al., 2017), indicators outer loadings should be above 0.7 . the value of $r$ square for profession $1,2,3,4,5$ are $0.050,0.057,0.051,0.085,0.075$ respectively as shown in figure 4,5,6,7,8. For the area of social sciences value of R square 0.02 gives small effect, 0.09 gives medium effect and 0.25 gives large effect (Jacob cohen, 1988).

\section{Discussion}

Based on the findings of above table, those variables that have p-value less than 0.05 show positive impact on profession selection decision. In business and management sciences the factors growth opportunities and occupational charm show insignificant affect, on the other hand personal interest, self-esteem and societal influence show significant impact on the selection of business and management sciences profession as shown in table 13. In medical profession, growth opportunities, occupational charm, personal interest and societal influence show insignificant affect. The factors that affect the selection of medical profession is self-esteem and self-efficacy which shows p-values less than 0.05 as shown in table 14. In pharmacy profession growth opportunities, psychological factor, self-efficacy, self-esteem and societal influence have positive impact and occupational charm, personal interest show insignificant impact in the selection of pharmacy profession (table 15). The factors that affect the selection of engineering profession are psychological, self-efficacy and societal influence, on the other hand growth opportunities, occupational charm and self-esteem shows insignificant impact (table 16). In the selection of agriculture profession growth opportunities, psychological factor and selfesteem show significant impact and occupational charm, personal interest, self-efficacy and societal influence shows insignificant affect (table 17).

The results of our study is unique as compared to previous studies for instance, growth opportunities was a significant factor according to the research conducted by (Nauman, 2014) but our study showed that for the students of Karachi, personal interest, self-esteem and societal influence is significant for management and sciences profession. Similarly for pharmacy (Eiland et al., 2010) stated that salary is not a significant factor and (Nauman, 2014) stated that occupational charm is a significant factor, as compared to this our study revealed the new factor which is psychological affects in the selection of pharmacy profession. Similarly for engineering, (Wilkinson, 2006) identify the factor "mobility" that affects the engineering students in UK, as compared to this our study identified societal influence is the significant factor in Pakistan. So in short the results of our study clearly showed that factors affect career choices is culturally induced. 


\section{Conclusion}

Profession selection was not so difficult in olden days, students choose profession of their parents but in this era, profession selection is a problem due to variety of occupations and their market demand.

This study examined more than 500 students from different educational backgrounds to identify the factors that affect profession selection, these factors are growth opportunities that affect the agriculture and pharmacy profession. Personal interest affects the business and management sciences. Self-esteem affects the business and management sciences, medical, pharmacy and agriculture profession. Self-efficacy affects the medical, pharmacy, engineering profession. Societal influence affects the business and management sciences and engineering profession. Psychological factor affects the pharmacy, engineering and agriculture profession. PROMETHEE multi-criteria decision making method also applied for ranking the professions and medical profession comes first among all other profession followed by engineering profession due to the positive net preference flows. Business administration, pharmacy and agriculture have ranked low due to the negative outranking values

The findings of our study have displayed and underlined the importance of "self-esteem" and "selfefficacy" in the selection of all above mentioned professions as these two factors show significant impact among all professions. It means people select professions that have high influence, status, prestige and lifestyle. The profession selection decisions of students are based on self-confidence, beliefs on their abilities and belief on the positive outcomes of the decision. The findings of the study support social cognitive theory given by (Lent $\&$ Brown, 1996). Other factors that identified in our study like growth opportunities, occupational charm, societal influence and personal interest, supports the three dimensional framework given by (Carpenter \& foster, 1977) which is widely used in career selection, it includes intrinsic, extrinsic and interpersonal factors. This study covers the gap and open up the doors for career guidance and counselling in Pakistan. Moreover this research provide insights to those students who wants to start their career by selecting the any of the above five mentioned profession. In addition, this research provide a valuable information and implications to the policy makers and industries recruiters as to what factors students keep in mind and their expectations when they decide to associate with these professions. The instrument of this research was administered in Pakistan which is a low income country so other developed or high income countries used this to test the cultural differences.

\section{References}

Agarwala, T. (2008a). Factors influencing career choice of management students in India. Career Development International, 13(4), 362-376. https://doi.org/10.1108/13620430810880844

Agarwala, T. (2008b). Factors influencing career choice of management students in India. Career Development International, 13(4), 362-376. https://doi.org/10.1108/13620430810880844

Albadvi, A., Chaharsooghi, S. K., \& Esfahanipour, A. (2006). Decision making in stock trading: An application of PROMETHEE. European Journal of Operational Research, 177(2), 673-683. https://doi.org/10.1016/j.ejor.2005.11.022

Bai, L. (1998). Monetary reward versus the national ideological agenda: Career choice among Chinese university students. Journal of Moral Education, 27(4), 525-540. https://doi.org/10.1080/0305724980270406

Ballout, H. I. (2007). Career success. Journal of Managerial Psychology, 22(8), 741-765. https://doi.org/10.1108/02683940710837705

Baron, R. M., \& Kenny, D. A. (1986). The Moderator-Mediator Variable Distinction in Social Psychological Research. Conceptual, Strategic, and Statistical Considerations. Journal of Personality and Social Psychology, 51(6), 1173-1182. https://doi.org/10.1037/0022-3514.51.6.1173

Beynon, J., Toohey, K., Journal, N. K.-C. E. S., \& 1998, U. (1998). Do visible minority students of Chinese and South Asian ancestry want teaching as a career?: Perceptions of some secondary school students in Vancouver, BC. Go.Galegroup.Com. Retrieved from https://go.galegroup.com/ps/i.do?id=GALE\%7CA82883535\&sid=googleScholar\&v=2.1\&it=r\&linkaccess $=\mathrm{abs} \& \mathrm{issn}=00083496 \& \mathrm{p}=\mathrm{AONE} \& \mathrm{sw}=\mathrm{w}$

Brans, J. P., \& De Smet, Y. (2016). PROMETHEE methods. International Series in Operations Research and Management Science, 233, 187-219. https://doi.org/10.1007/978-1-4939-3094-4_6

Carpenter \& foster. (1977). citation-288894311.

Choo, L. S., Norsiah, M., \& Tan, L. I. (2012). What drives the career choice among engineers? A case in Malaysian manufacturing plant. International Journal of Research Studies in Management, 1(2), 15-24. https://doi.org/10.5861/ijrsm.2012.v1i2.60

Ciarrochi, J., \& Bilich, L. (n.d.). Measures Package. Retrieved from http://ueb.ro/psihologie/docs/Psihologie_pozitiva_teste_si_scale.pdf\#page $=61$

Dick, T. P., \& Rallis, S. F. (2006). Factors and Influences on High School Students' Career Choices. Journal for Research in Mathematics Education, 22(4), 281. https://doi.org/10.2307/749273

Eiland, L. S., Flowers, S. K., Andurkar, S. V., O’Brocta, R., Prabhu, S., \& Medon, P. J. (2010). A comparative 
study of student and faculty perspectives regarding career opportunities in pharmacy academia. Currents in Pharmacy Teaching and Learning, 2(1), 39-51. https://doi.org/10.1016/j.cptl.2009.12.005

Fejgin, N., Ephraty, N., \& Ben-Sira, D. (1995). Work Environment and Burnout of Physical Education Teachers. Journal of Teaching in Physical Education, 15(1), 64-78. https://doi.org/10.1123/jtpe.15.1.64

Flora., K. (2010). Factors influencing pharmacy students' choice of major and its relationship to anticipatory socialization. American Journal of Pharmaceutical Education, 74(4), 75. Retrieved from http://www.embase.com/search/results?subaction=viewrecord\&from=export\&id=L359799340\%0Ahttp:// wt3cf4et21.search.serialssolutions.com?sid=EMBASE\&issn=15536467\&id=doi:\&atitle=Factors+influenci ng+pharmacy + students $\% 27+$ choice + of + major+and + its + relationship + to + an

Flum, H., Behavior, D. B.-J. of V., \& 2000, U. (2000). Reinvigorating the study of vocational exploration: A framework for research. Elsevier. Retrieved from https:/www.sciencedirect.com/science/article/pii/S0001879100917214

Hackett, Brown, L. (1994). SCT part 2.pdf.

Hair, J. F., Hult, G. T. M., \& Ringle, C. M. (2017). A Primer on Partial Least Squares Structural Equation Modeling ( $P L S-S E M$ ).

Henseler, J., Hubona, G., \& Ash, P. (2016). Using PLS path modeling in new technology research : updated guidelines. https://doi.org/10.1108/IMDS-09-2015-0382

Hu, L., \& Bentler, P. M. (1999). Cutoff criteria for fit indexes in covariance structure analysis: Conventional criteria versus new alternatives. Structural Equation Modeling: A Multidisciplinary Journal, 6(1), 1-55. https://doi.org/10.1080/10705519909540118

Jacob cohen. (1988). Statistical power analysis for the behavioral sciences.

Jones, W. a, \& Larke Jr., A. (2003). Factors Influencing Career Choices of Ethnic Minorities in Agriculture. NACTA Journal, 11-17.

K.E., H., S.J., D., W.N., K., M.J., F., M., M., P.S., O., ... M.D., S. (2008). Factors associated with medical students' career choices regarding internal medicine. JAMA - Journal of the American Medical Association, 300(10), 1154-1164. https://doi.org/10.1001/jama.300.10.1154

kassebaum \& szenas. (1993). Academic Medicine Volume 69 issue 21994 [doi 10.1097_00001888-19940200000027] Kassebaum, D G; Szenas, P L -- Factors influencing the specialty choices of 1993 medical school graduates [published e.pdf.

Lent, R. W., \& Brown, S. D. (1996). Social Cognitive Approach to Career Development: An Overview. Career Development Quarterly, 44(4), 310-321. https://doi.org/10.1002/j.2161-0045.1996.tb00448.x

M Rosenberg - Acceptance and commitment therapy. (1965). Rosenberg self-esteem scale (RSE). Ueb.Ro. Retrieved from http://ueb.ro/psihologie/docs/Psihologie_pozitiva_teste_si_scale.pdf\#page=61

Nauman, M. (2014). www.econstor.eu.

Ng, E. S. W., Burke, R. J., \& Fiksenbaum, L. (2008). Career choice in management: Findings from US MBA students. Career Development International, 13(4), 346-361. https://doi.org/10.1108/13620430810880835

paolillo \& estes. (1992). empirical analysis of career choice factors among accountants, attorneys, engineers and physicians. 57(4), 785-793.

Schein, E. (1978). Career dynamics: Matching individual and organizational needs.

Schein, E. H. (2001). Career Anchors Revisited: Implications for Career Development in the 21st Century. 1-9.

Smith, J. (n.d.). motivation questionnaire. Retrieved from http://www.eqtest.com/Reports/mq_sample_report.pdf

Square, L., Approach, P. L. S., Surienty, L., Lo, T. R. M., \& Natasha, A. (2013). Quality of Work Life and Turnover Intention : A Partial. https://doi.org/10.1007/s11205-013-0486-5

Taylor, K. M., \& Popma, J. (1990). An examination of the relationships among career decision-making selfefficacy, career salience, locus of control, and vocational indecision. Journal of Vocational Behavior, 37(1), 17-31. https://doi.org/10.1016/0001-8791(90)90004-L

Wilkinson, S. (2006). Career Development International The factors affecting the career choice of male and female civil engineering students in the UK Article information. https://doi.org/10.1108/13620439610130641

Zikic, J., \& Richardson, J. (2007). Unlocking the careers of business professionals following job loss: sensemaking and career exploration of older workers. Canadian Journal of Administrative Sciences / Revue Canadienne Des Sciences de l'Administration, 24(1), 58-73. https://doi.org/10.1002/cjas.5 